\title{
The Properties of Phospholipase Enzymes in Staphylococcal Toxins
}

\author{
BY HAZEL M. DOERY, B. J. MAGNUSSON, J. GULASEKHARAM \\ AND JOAN E. PEARSON \\ Commonwealth Serum Laboratories, Parkville, Victoria, Australia
}

(Received 1 April 1965)

\begin{abstract}
SUMMARY
Two phospholipase enzymes have been identified in toxic preparations from Staphylococcus aureus, each having a mode of action like that of phospholipase C. One enzyme hydrolysed phosphatidyl inositol and lysophosphatidyl inositol, while the other hydrolysed sphingomyelin and lysophosphatidyl choline. The latter enzyme was always associated with $\beta$-haemolysin activity and it is concluded that $\beta$-haemolysin, sphingomyelinase and lysophospholipase are activities of one protein. A phospholipase $\mathbf{A}$ was also detected in a toxic preparation from an $\alpha \beta$ strain. A study of cultural conditions showed that this enzyme was produced under a variety of conditions, but only when the $\beta$-haemolysin activity was high.
\end{abstract}

\section{INTRODUCTION}

In preliminary communications (Magnusson, Doery \& Gulasekharam, 1962; Doery, Magnusson, Cheyne \& Gulasekharam, 1963) it was reported that toxic preparations from a strain of Staphylococcus aureus (S. pyogenes; strain B.S.M. 24) contained two enzymes which were separable by curtain electrophoresis. These enzymes hydrolysed the phosphatidyl inositols, (phosphatidyl inositol and lysophosphatidyl inositol) and sphingomyelin, respectively. It was also shown that the crude toxic culture fluid hydrolysed lysophosphatidyl choline. In each case, the mode of hydrolysis of the phospholipids was similar to that caused by phospholipase $\mathrm{C}$.

The distribution of these activities in toxic preparations from a number of strains of $S$. aureus was examined. Inositol phospholipase was found in all the toxic culture fluids which contained $\alpha$-haemolysin, while sphingomyelinase and lysophospholipase were found in all toxic preparations which contained both $\alpha$ and $\beta$-haemolysins. No phospholipase activity was detected in culture fluids from non-haemolytic coagulase-negative strains.

Toxic preparations from $\alpha \beta$-haemolytic variants of Staphylococcus aureus which had arisen from parent $\alpha$-strains were then examined. It was shown that the toxic preparations from the $\alpha \beta$-variants had acquired both sphingomyelinase and lysophospholipase activity. To examine the possible relationship between the phospholipase enzymes and the $\alpha$ - and $\beta$-haemolysins, the latter components were separated by fractional precipitation with $\left(\mathrm{NH}_{4}\right)_{2} \mathrm{SO}_{4}$ and chromatography on hydroxyl-apatite.

The present communication describes the mode of action, the properties and distribution of the phospholipase enzymes in staphylococcal toxic preparations. The 
relationship of these enzymes to the staphylococcal haemolysins will be discussed. Evidence is presented to support the conclusion that $\beta$-haemolysin, sphingomyelinase and lysophospholipase are activities of one enzyme.

\section{METHODS}

Staphylococcal toxic preparations. The toxic preparations were culture fluids of the organisms grown for 4 days in saline within cellophane sacs suspended in Dolman's broth (Dolman, 1934). The whole culture unit was agitated on a shake table in a warm room at $37^{\circ}$; in a few cases, the shake table was not used, a mixture of oxygen $+\mathrm{CO}_{2}(\%, \mathrm{v} / \mathrm{v} 80+20)$ was gently bubbled through the contents of the sac. Toxic preparations from an $\alpha \beta$ strain (Staphylococcus aureus, strain B.s.M. 24) made by the latter method was used for the separation of enzymes by curtain electrophoresis.

Toxic preparations for separation of the haemolysins on hydroxylapatite columns were prepared in cellophane sacs, bubbling oxygen $(\%, v / v)+\mathrm{CO}_{2}(\%, v / v)$ carbogen for strain $\mathrm{CN} 56$ ( $\alpha$ strain) and air for strain 1061-17 ( $\alpha \beta$-haemolytic strain of bovine origin).

To examine the conditions which favoured the production of phospholipase $A$, toxic preparations were made from strains grown directly in Dolman's broth in static cultures (2-7 days incubation at $37^{\circ}$ ) and in 2-4 day cultures through which air or oxygen $+\mathrm{CO}_{2}$ carbogen was gently bubbled.

Thiomersalate $(0.01 \%, \mathrm{w} / \mathrm{v})$ was added to all toxic preparations.

Buffers. For quantitative estimations of enzymes, $0.3 \mathrm{M}$-ammonium acetate adjusted to the desired $\mathrm{pH}$ value with either $0.3 \mathrm{M}$-acetic acid or $0.3 \mathrm{M}-\mathrm{NH}_{4} \mathrm{OH}$ was used. For chromatography on hydroxylapatite, a stock solution of $0.5 \mathrm{M}$-phosphate buffer (pH 6.7) was prepared according to Woodin (1959). Buffers of concentrations ranging from $0.05 \mathrm{M}$ - to $0.25 \mathrm{M}$-phosphate were made by diluting the stock solution in water or $0.15 \mathrm{M}-\mathrm{NaCl}$ without further $\mathrm{pH}$ adjustment.

Paper chromatography. For phospholipids the methods of Marinetti, Albrecht, Ford \& Stotz (1959) were used. For other compounds containing phosphorus, descending chromatography in the solvent ethylmethylketone $+n$-butanol saturated with water $+n$-butanol $n$-propanol $+98-100 \%$ formic acid $(9+5+1+4$, by vol.; Gerlach, Weber \& Döring, 1955) was used.

\section{Substrates}

Phosphatidyl inositol. A commercial preparation of soy bean phosphatidyl choline was used as the source of this phospholipid. This was shown by quantitative paper chromatography to have the following percentage $(w / v)$ composition; phosphatidyl ethanolamine $22 \%$, phosphatidyl choline $28 \%$, phosphatidyl inositol $20 \%$ and lysophosphatidyl inositol $3 \%$ (Magnusson et al. 1962). For quantitative estimations the soy bean phosphatidyl choline was homogenized in an Omnimixer blender (1600 rev./min. for $5 \mathrm{~min}$.). The emulsion was dialysed against water to remove soluble phosphorus compounds, and the non-diffusible phospholipid used at a concentration which represented $10 \mu \mathrm{g}$. soy bean phosphatidyl choline $/ \mathrm{ml}$.

Sphingomyelin. This was prepared from a crude extract of beef heart (Pangborn, 1951) and purified by the method of Rapport \& Lerner (1958). When examined by paper chromatography, the product moved as a single component and failed to stain with ninhydrin. 
Phosphatidyl choline. Crude egg phosphatidyl choline was purified by chromatography on silica gel (Saunders, 1957), and held in chloroform solution until required.

Lysophosphatidyl choline. Phosphatidyl choline was hydrolysed by phospholipase A prepared as described by Doery \& Pearson (1961) and the resultant lysophosphatidyl choline purified as described by Saunders (1957). For quantitative estimations, aqueous emulsions of sphingomyelin, phosphatidyl choline and lysophosphatidyl choline were each used at a concentration of $5 \mathrm{mg} . / \mathrm{ml}$.

Human plasma. Thiomersalate $(0.02 \%, \mathrm{w} / \mathrm{v})$ and either cobalt or magnesium salts were added to citrated human plasma to provide a concentration (0.02$0.04 \mathrm{M}$ ) of $\mathrm{Co}^{2+}$ or $\mathrm{Mg}^{2+}$ in excess of that of the citrate ions.

Plasma phospholipids. These were extracted from freeze-dried citrated human plasma with successive lots of chloroform + methanol $(2+1$, by vol.). The solvent was removed from the pooled extracts in a Craig rotary evaporator, and the product dried in vacuo over phosphorus pentoxide.

Screening of toxic preparations for phospholipase enzymes. To detect inositol phospholipase, toxic preparations were placed in wells on $1 \%(w / v)$ agar plates containing $\mathrm{MgSO}_{4}(0.01 \%, \mathrm{w} / \mathrm{v})$, soy bean phosphatidyl choline $(1 \%, \mathrm{w} / \mathrm{v})$ and thiomersalate $(0.01 \%, w / v)$. Plates were incubated at $37^{\circ}$ for periods up to $48 \mathrm{hr}$. Opaque areas which surrounded the wells as well as control areas were removed and extracted twice with $10 \mathrm{ml}$. chloroform + methanol $(2+1$, by vol.) by shaking for $2 \mathrm{hr}$. The extracts were pooled and evaporated to dryness at $45^{\circ}$ under a stream of air and reconstituted in chloroform + methanol $(2+1$, by vol.). The extract was analysed for phosphorus, and samples containing $10 \mu \mathrm{g}$. phosphorus were examined for phospholipids by paper chromatography. The relative loss of phosphatidyl inositol in toxin-treated substrate compared with controls indicated specific action on the phospholipid.

To detect sphingomyelinase, lysophospholipase and phospholipase activity, $0.5 \mathrm{ml}$. of the toxic preparation was mixed with $1 \mathrm{ml}$. human plasma, and shaken at $37^{\circ}$ for periods up to $48 \mathrm{hr}$. The mixture was extracted twice with chloroform + methanol $(2+1$, by vol) by shaking for $1 \mathrm{hr}$. The pooled extracts were treated in the manner described for the detection of inositol phospholipase; loss of phospholipids indicated the presence of the respective enzymes. When a relative increase in lysophosphatidyl choline occurred, the presence of phospholipase $\mathbf{A}$ was indicated.

Estimation of inositol phospholipase, sphingomyelinase and lysophospholipase activities. Mixtures of $0.2 \mathrm{ml}$. toxic preparation, $0.5 \mathrm{ml}$. phospholipid emulsion and $0.5 \mathrm{ml} .0 .3 \mathrm{M}$-ammonium acetate buffer $(\mathrm{pH} 7)$ containing $0.01 \%(\mathrm{w} / \mathrm{v}$ ) thiomersalate were shaken at $37^{\circ}$ for $2.5 \mathrm{hr}$. After the addition of $0.25 \mathrm{ml}$. albumin $(5 \%, \mathrm{w} / \mathrm{v})$ $0.5 \mathrm{ml}$. of trichloroacetic acid (TCA; $20 \%, \mathrm{w} / \mathrm{v}$ ) was added. The precipitate was removed by centrifugation at $70,000 \mathrm{~g}$ for $30 \mathrm{~min}$. in a preparative ultracentrifuge at $4^{\circ}$. Samples were evaporated in a boiling-water bath in a stream of air and analysed for phosphorus. Relative activities were expressed as $\mu$ moles phospholipid hydrolysed/ml. toxic preparation in $2 \cdot 5 \mathrm{hr}$.

Determination of the end products of inositol phospholipase, sphingomyelinase and lysophospholipase

The product containing phosphorus. Inositol phosphate was detected by paper electrophoresis in the TCA supernatant fluid of the reaction mixture after removal 
of the TCA by extraction with diethylether. Paper electrophoresis was done with a Spinco hanging strip cell, Model $\mathrm{R}$, at $400 \mathrm{~V}$. for periods up to $20 \mathrm{hr}$, with pyridine + acetic acid + water $(25+1+225$, by vol.) as the buffer. Dextran was used as a control for electro-osmosis. At the conclusion of the run, the paper was treated for the detection of phosphorus (Hanes \& Isherwood, 1949). Inositol phosphate and glycerophosphoryl choline were used as markers. For sphingomyelinase and lysophospholipase, in each case a zero-time reaction mixture and one which had been allowed to proceed to completion, were freeze-dried, further dried in vacuo over silica gel, then extracted with chloroform. The residues were extracted with water. Samples of the chloroform and aqueous extracts were analysed for phosphorus and examined by paper chromatography.

Lipid reaction products. Reaction mixtures which had proceeded to completion were freeze-dried and the product extracted three times with $3 \mathrm{ml}$. light petroleum (b.p. $40-60^{\circ}$ ). The pooled extracts were dialysed in a rubber membrane against light petroleum as described by van Beers, de Iongh \& Boldingh (1958). The diffusate was analysed for ester groups and free fatty acids. In addition, in the case of sphingomyelinase, the chloroform extracts of both a zero-time and a completed reaction mixture were analysed for nitrogen. In the case of lysophospholipase, ester group analyses were carried out on similar chloroform extracts.

Measurement of haemolytic activity. Erythrocytes from citrated rabbit blood or defibrinated sheep blood were washed 3 times with $\mathrm{NaCl}(0.15 \mathrm{M})$ and a suspension of them $(2 \%, v / v)$ prepared in this saline or the appropriate diluent. For the measurement of $\alpha$-haemolysin, rabbit erythrocytes and crude toxic preparation were diluted in saline, but when purified toxic preparations were examined, both the toxic preparations and the erythrocytes were diluted in saline phosphate buffer ( $\mathrm{pH} 7)$; Jackson \& Little (1957). Equal volumes $(0.5 \mathrm{ml}$.) of toxic preparation and rabbit erythrocytes $(2 \%, \mathrm{v} / \mathrm{v})$ were incubated together for $1 \mathrm{hr}$, then centrifuged briefly to remove unhaemolysed erythrocytes. One drop of potassium ferricyanide $(1 \%, \mathrm{w} / \mathrm{v})$ was added to each sample of supernatant fluid, and the extinction read at $630 \mathrm{~m} \mu$. A standard curve relating extinction and percentage haemolysis was obtained from appropriate dilutions of blood in water. For $\beta$-haemolysin, sheep erythrocytes and crude toxic preparation were diluted in saline. Purified toxic preparation was diluted in bovine serum albumin $(0.2 \%, \mathrm{w} / \mathrm{v})$ in saline, giving approximately sixfold activation. Equal volumes of toxic preparation and sheep erythrocytes were incubated together for $1 \mathrm{hr}$, then held for $30 \mathrm{~min}$. in an ice bath at $4^{\circ}$ before estimating the percentage haemolysis in the manner described for $\alpha$-haemolysin. For both haemolysins, the dilution of toxic preparation which produced $50 \%$ haemolysis was determined. The reciprocal of this dilution was taken to be the number of units of haemolysin/ml.

Staphylococcal antitoxin. This was a commercial product prepared in these Laboratories by using a mixture of toxic preparations from $\alpha$-and $\alpha \beta$-strains as immunizing antigens.

Antigenic components. These were detected on Ouchterlony plates in which toxic preparations at protein concentrations of 0.5-1 mg./ml. were diffused against staphylococcal antitoxin at appropriate dilutions.

Protein concentration. The extinction was measured at $280 \mathrm{~m} \mu$ and calculation of the protein concentration was based on the assumption that $E_{280 \mathrm{~m} \mu}^{0.1 \%}$ was $1 \cdot 0$. 
Analytical methods. Phosphorus was estimated by the method of Brown (1954); ester groups by the method of Shapiro (1953); nitrogen by a micro-Kjeldahl procedure. Fatty acid was estimated by titration against $\mathrm{NaOH}(0.01 \mathrm{~N})$, by using a Reyberg ultramicroburette with thymol blue as indicator. Proteolytic activity was detected in toxic preparations by a modification of the method of Levy (1952). Toxic preparations were placed in wells on plates containing gelatine $(0.5 \%, \mathrm{w} / \mathrm{v})$ in saline agar. The plates were incubated at $37^{\circ}$ for $24 \mathrm{hr}$, then a saturated solution of $\mathrm{HgCl}_{2}$ in $10 \% \mathrm{HCl}$ was poured over the agar. Clear zones around the wells indicated proteolytic activity. Lipase activity was detected by the hydrolysis of maize oil in agar in plates by the method of Richou, Richou, Quinchon \& Pantaléon (1960).

Separation of inositol phospholipase and sphingomyelinase by curtain electrophoresis. The toxin from Staphylococcus aureus strain B.S.M. 24, was dialysed against veronal buffer ( $\mathrm{pH} 8 \cdot 6 ; \mathrm{U}, 0 \cdot 02$ ). Electrophoresis was carried out with the same buffer, in a Beckmann/Spinco continuous flow paper electrophoresis cell, Model C.P., for $44 \mathrm{hr}$, at $4^{\circ}, 630 \mathrm{~V}$ and a current of $45 \mathrm{~mA}$. The fractions were dialysed against $\mathrm{NaCl}(0.15 \mathrm{M})$ containing thiomersalate $(0.01 \%, \mathrm{w} / \mathrm{v})$ and analysed for inositol phospholipase and sphingomyelinase.

Purification of $\alpha$ - and $\beta$-haemolysins from toxic preparations of strains $C_{N} 56$ and 1061-17, respectively. Crude toxic preparation (culture fluid) was freeze-dried, reconstituted in water to $1 / 10$ of the original volume and then centrifuged. By a procedure essentially that of Bernheimer \& Schwartz (1963), the haemolysins in the supernatant fluid were partially purified by repeated precipitation with $\left(\mathrm{NH}_{4}\right)_{2} \mathrm{SO}_{4}$ and finally obtained in a fraction which was soluble in $40 \%$ and insoluble in $60 \%$ saturated $\left(\mathrm{NH}_{4}\right)_{2} \mathrm{SO}_{4}$. This fraction was then dissolved in the minimum volume of $20 \%$ saturated $\left(\mathrm{NH}_{4}\right)_{2} \mathrm{SO}_{4}$ and dialysed against $0.05 \mathrm{M}$ - or $0 \cdot 1 \mathrm{M}$-phosphate buffer ( $\mathrm{pH} 6 \cdot 7$ ). The dialysed solution (dialysis residue) was held for chromatography on hydroxylapatite.

Hydroxylapatite was prepared by the method of Tiselius, Hjerten \& Levin (1956) with the modifications of Woodin (1959) and Jackson (1963). The hydroxylapatite columns were $1.8 \mathrm{~cm}$. wide and optimum separations of components were obtained when 12-15 mg. protein were applied $/ \mathrm{cm}$. height of hydroxylapatite column. Elution was continued with increasing concentrations of phosphate buffer, and finally in the case of $\beta$-haemolysin with buffer in $0.15 \mathrm{M}-\mathrm{NaCl}$. $E_{280 \mathrm{~m} \mu}$ of eluates ( $2 \mathrm{ml}$.) was read, then thiomersalate was added to each eluate to $0.01 \%(w / v)$. In the case of $\beta$-haemolysin, bovine serum albumin was also added (final concentration $2 \%, w / v$ ) as a stabilizer.

\section{RESULTS \\ Mode of action of inositol phospholipase, sphingomyelinase and lysophospholipase}

These enzymes were shown to have a common mode of action. With each enzyme, phosphorus was found in the TCA filtrate from the reaction mixture. With inositol phospholipase, the phosphorus was contributed by a single compound and identified by paper electrophoresis as inositol phosphate. Since this enzyme was inactive on purified phosphatidyl inositol, no quantitative phosphorus balance was attempted. With both sphingomyelinase and lysophospholipase, all the phosphorus of the chloroform extract of the zero-time reaction mixture was found in the aqueous 
extract of the reaction mixture which had proceeded to completion (Table 1a), indicating complete hydrolysis of the substrates. With both enzymes the phosphorus in the latter extract was contributed by a single phosphorus-staining compound, identified by paper chromatography as phosphoryl choline.

\section{Table 1. End-product analysis of staphylococcal sphingomyelinase and lysophospholipase action}

(a) Distribution of phosphorus in zero-time and complete reaction mixtures (18 $\mathrm{hr}$ ), expressed as a \% of total phosphorus of the zero-time reaction mixture.

$\begin{array}{cccc}\text { Enzyme } & \text { Reaction } & \overbrace{\mathrm{CHCl}_{3} \text { extract }} & \text { Aqueous extract } \\ \text { time (hr) } & 0 & 96 & 4 \\ \text { Lyhingomyelinase } & 18 & 2 & 93 \\ & 0 & 97 & 8 \\ \text { Lysophospholipase } & 18 & 8 & 100\end{array}$

(b) Lipid reaction products. Recovery of nitrogen and ester groups in chloroform extracts of zero-time and complete $(24 \mathrm{hr}$ ) reaction mixtures.

$\begin{array}{cccr}\text { Enzyme } & \begin{array}{c}\text { Reaction } \\ \text { time (hr) }\end{array} & \begin{array}{c}\text { Nitrogen } \\ (\%)\end{array} & \begin{array}{r}\text { Ester } \\ (\%)\end{array} \\ \text { Sphingomyelinase } & 0 & 100 & \text {. } \\ & 24 & 110 & \text {. } \\ \text { Lysophospholipase } & 0 & . & 100 \\ & 24 & . & 88\end{array}$

When the reaction mixtures were dialysed against light petroleum, esterified fatty acids but no phosphorus were found in diffusates of reaction mixtures containing the phosphatidyl inositols or lysophosphatidyl choline. No free fatty acids were found. In addition, with lysophospholipase the ester group concentration of the chloroform extract of the completed reaction mixture $(24 \mathrm{hr})$ was unchanged from that of the zero-time mixture (Table $1 b$ ).

In the case of sphingomyelinase, the nitrogen of the chloroform extract of the zero-time sample was completely recovered in the chloroform extract of the reaction mixture which had proceeded to completion. Since no free fatty acid was found and phosphoryl choline was the only reaction product containing phosphorus, the total recovery of the nitrogen in the chloroform extract is in keeping with the formation of $\mathrm{N}$-acyl sphingosine. No estimation of the $\mathrm{N}$-acyl group was attempted.

From the above observations, the following mechanisms, each like that of phospholipase $\mathrm{C}$, are indicated:

phosphatidyl inositol $+\mathrm{H}_{2} \mathrm{O} \longrightarrow$ diglyceride + inositol phosphate sphingomyelin $+\mathrm{H}_{2} \mathrm{O} \longrightarrow \mathrm{N}$-acyl sphingosine + phosphoryl choline lysophosphatidyl choline $+\mathrm{H}_{2} \mathrm{O} \longrightarrow$ monoglyceride + phosphoryl choline

\section{Properties of the enzymes}

Optimum $p H$ value of reaction. Figure 1 shows the relationship between the $\mu$ moles phospholipid hydrolysed and $\mathrm{pH}$ value for each enzyme. It can be seen that the optimum activity of the inositol phospholipase was at $\mathrm{pH} 4 \cdot 6$, while the 
maximum activity of the sphingomyelinase and the lysophospholipase was at $\mathrm{pH} 7 \cdot 5$.

Optimum temperature of reaction. Inositol phospholipase showed little change in activity between 20 and $40^{\circ}$ but rapid loss of activity occurred at temperatures above $40^{\circ}$. Both sphingomyelinase and lysophospholipase showed maximum activity near $40^{\circ}$.

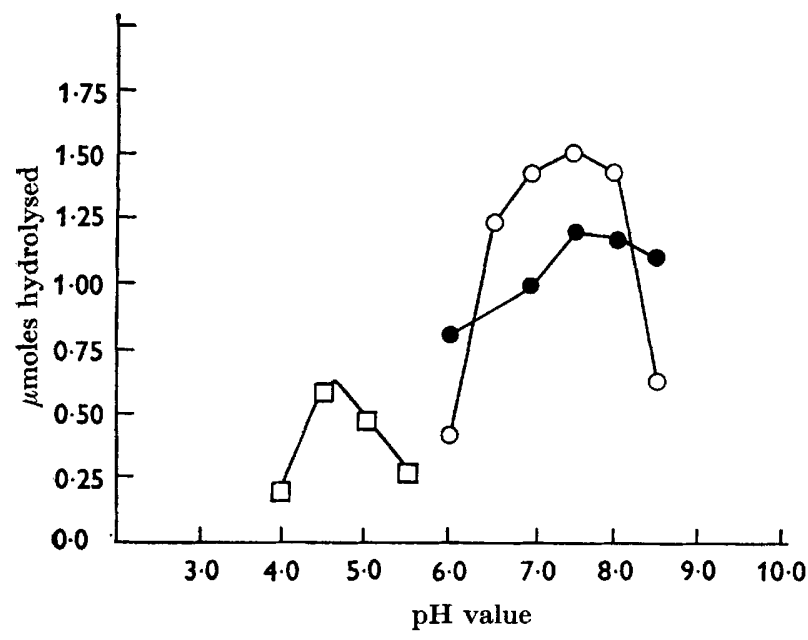

Fig. 1

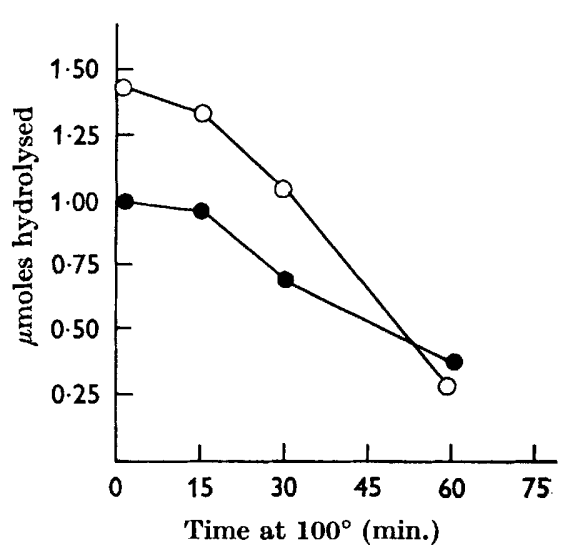

Fig. 2

Fig. 1. Effect of pH value of incubation mixture on the activity of enzymes. $\square$, inositol phospholipase; $O$, lysophospholipase; $O$, sphingomyelinase.

Fig. 2. Stability of enzymes held at $100^{\circ}$. Toxic preparation at $\mathrm{pH} 7 \cdot 2$, was held in sealed ampoules at $100^{\circ}$ for the times indicated and enzyme activity then determined. O, lysophospholipase; 0 , sphingomyelinase.

Stability to heat. Owing to the limited amounts of fractions available from the curtain electrophoresis of crude toxic preparations, it was not possible to determine the effect of heat on the inositol phospholipase. Figure 2 shows that after $1 \mathrm{hr}$ at $100^{\circ}, 33$ and $20 \%$ of the sphingomyelinase and lysophospholipase activity, respectively, of the unheated toxic preparations remained.

Effect of enzyme concentration and time of incubation. The relationship between the concentration of enzyme and the $\mu$ moles phospholipid hydrolysed was linear for the three enzymes over the ranges used for these experiments, and became typically enzymic when excess enzyme was used. A linear relationship was found between time of incubation and $\mu$ moles phospholipid hydrolysed, over the region where the reaction was not limited by lack of substrate.

Inhibition of enzyme activity by staphylococcal antitoxin. Figure 3 shows the effect of commercial antitoxin on the activities of the enzymes. In all cases, the relationship between the amount of antitoxin used to inhibit the enzyme and the resulting enzyme activity was linear.

Effect of metal ions on activity of enzymes. Following the observation by Robinson, Thatcher \& Gagnon (1958) that $\beta$-haemolysin was activated by $\mathrm{Co}^{2+}$, the following tests were made. Both the sphingomyelinase and lysophospholipase were activated 
by the addition of $\mathrm{Co}^{2+}$ or $\mathrm{Mg}^{2+}, \mathrm{Co}^{2+}$ being more effective than $\mathrm{Mg}^{2+} ; \mathrm{Ca}^{2+}$ inhibited both enzymes. Figure 4 shows that with equimolar concentrations of $\mathrm{Mg}^{2+}$, similar patterns of activation of both enzymes were obtained, the average maximum activation of the sphingomyelinase and lysophospholipase being $111 \%$ $(105,105,124)$ and $113 \%(107,111,122)$, respectively. No such activation of the inositol phospholipase was found. Equimolar concentrations of $\mathrm{Ca}^{2+}$ inhibited the sphingomyelinase and the lysophospholipase to the same degree, the average maximum inhibition being $63 \%(51,69,73)$ and $58 \%(55,58,61)$, respectively.

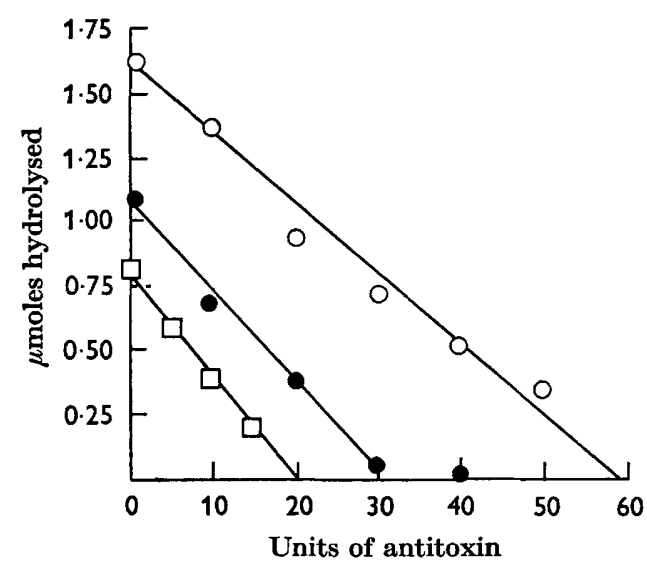

Fig. 3

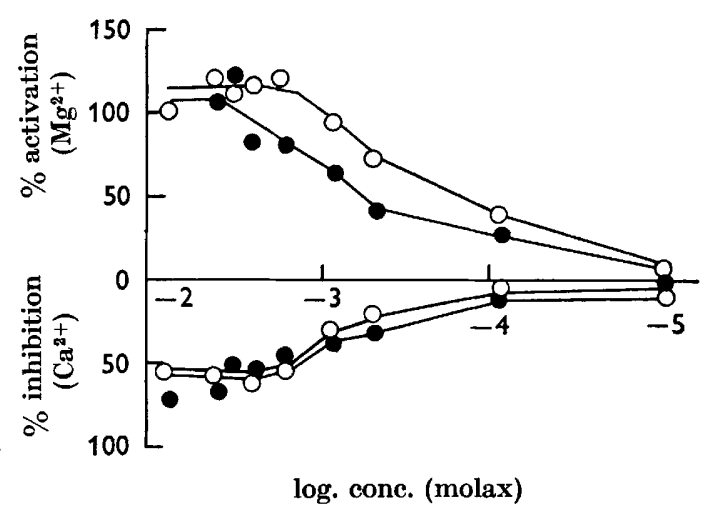

Fig. 4

Fig. 3. Inhibition of enzyme activity by antitoxin. Toxic preparation $(0 \cdot 25 \mathrm{ml}$.) and antitoxin ( $1 \mathrm{ml}$.; 0-50 units) were held at $37^{\circ}$ for $45 \mathrm{~min}$. and enzyme activity determined. $\square$, inositol phospholipase; $\bigcirc$, lysophospholipase; $O$, sphingomyelinase.

Fig. 4. Effect of the concentration of $\mathrm{Ca}^{2+}$ and $\mathrm{Mg}^{2+}$ on the sphingomyelinase and lysophospholipase activities. 0 , sphingomyelinase; $O$, lysophospholipase.

\section{Table 2. Distribution of inositol phospholipase, sphingomyelinase and} lysophospholipase among strains of Staphylococcus aureus

S. aureus strain

Coagulase-positive, haemolytic $\alpha$-haemolytic $\alpha$-haemolytic $\alpha \beta$-haemolytic

Coagulase-negative, nonhaemolytic

Source
bovine (4)*
human (4)
bovine (7)
milk (1)
air (1)
human (3)

Sphingophospholipase
Lysophospholipase

* Figures in parentheses represent the number of strains examined.

\section{Distribution of enzymes in staphylococcal toxins}

Table 2 shows the distribution of phospholipase enzymes in toxic preparations from a number of $\alpha \beta$-strains and $\alpha$-strains of Staphylococcus aureus, and also nonhaemolytic coagulase-negative strains. It can be seen that inositol phospholipase $\mathrm{C}$ 
was detected in strains which produced $\alpha$-haemolysin, while sphingomyelinase and lysophospholipase were found only in strains which also produced $\beta$-haemolysin. No phospholipase activity was detected in culture fluids from the non-haemolytic coagulase-negative strains.

Table 3. Distribution of enzymes in toxic preparations from strains of Staphylococcus aureus and their variants

$\begin{array}{ccccc}\text { S. aureus strain } & \text { Haemolysin } & \begin{array}{c}\text { Inositol } \\ \text { phospholipase }\end{array} & \begin{array}{c}\text { Sphingo- } \\ \text { myelinase }\end{array} & \begin{array}{c}\text { Lyso- } \\ \text { phospholipase }\end{array} \\ \text { No. II } & \alpha & + & - & - \\ \text { Variant } & \alpha \beta & + & + & + \\ \text { No. 1873 } & \alpha & + & - & - \\ \text { Variant } & \alpha \beta & + & + & + \\ \text { Wood } & \alpha & + & - & - \\ \text { Variant } & \alpha \beta & + & + & + \\ \text { No. 2063 } & \alpha & + & - & - \\ \text { Variant } & \alpha \beta & + & + & +\end{array}$

Table 4. Production of phospholipase $A$ in toxic preparations obtained under different cultural conditions from strains of Staphylococcus aureus

\begin{tabular}{|c|c|c|c|c|c|c|}
\hline \multirow{4}{*}{$\begin{array}{l}\text { S. aureus } \\
\text { strain }\end{array}$} & \multicolumn{3}{|c|}{ Culture conditions } & \multirow{3}{*}{\multicolumn{2}{|c|}{$\begin{array}{l}\text { Haemolysin activity } \\
\text { (units/ml.) } \\
\text { Erythrocytes }\end{array}$}} & \multirow{4}{*}{$\begin{array}{c}\text { Phospholipase } \\
\text { A }\end{array}$} \\
\hline & \multicolumn{2}{|c|}{ Bubbled with } & \multirow[b]{3}{*}{ Not bubbled } & & & \\
\hline & \multirow{2}{*}{$\begin{array}{c}\mathrm{O}_{2}+\mathrm{CO}_{2} \\
(80 \%+20 \% \\
\mathrm{v} / \mathrm{v})\end{array}$} & \multirow[b]{2}{*}{ Air } & & & & \\
\hline & & & & Rabbit & Sheep & \\
\hline \multirow[t]{4}{*}{709} & $\begin{array}{l}\text { 2-day } \\
\text { incubation }\end{array}$ & . & - & 128 & $\mathbf{3 5 0}$ & + \\
\hline & $\cdot$ & \multicolumn{2}{|l|}{$\begin{array}{l}\text { 2-day } \\
\text { incubation }\end{array}$} & 12 & 100 & - \\
\hline & . & $\cdot$ & $\begin{array}{l}\text { 2-day } \\
\text { incubation }\end{array}$ & 8 & 40 & - \\
\hline & - & • & $\begin{array}{l}\text { 5-day } \\
\text { incubation }\end{array}$ & 12 & 150 & - \\
\hline \multirow[t]{6}{*}{ 1061-17 } & $\begin{array}{l}\text { 2-day } \\
\text { incubation }\end{array}$ & $\cdot$ & $\cdot$ & 128 & $\mathbf{3 5 0}$ & + \\
\hline & . & $\begin{array}{l}\text { 2-day } \\
\text { incubation }\end{array}$ & - & 12 & 100 & - \\
\hline & $\cdot$ & $\begin{array}{l}\text { 4-day } \\
\text { incubation }\end{array}$ & - & 600 & 600 & + \\
\hline & $\cdot$ & $\cdot$ & $\begin{array}{l}\text { 2-day } \\
\text { incubation }\end{array}$ & 3 & 40 & - \\
\hline & . & $\cdot$ & $\begin{array}{l}\text { 5-day } \\
\text { incubation }\end{array}$ & 32 & 280 & - \\
\hline & - & $\cdot$ & $\begin{array}{l}\text { 7-day } \\
\text { incubation }\end{array}$ & 12 & 600 & + \\
\hline
\end{tabular}

Table 3 compares the distribution of phospholipase enzymes in toxic preparations from parent $\alpha$-strains and their $\alpha \beta$-haemolytic variants which arose during normal subculturing. In all cases the variant which acquired the $\beta$-haemolytic characteristic also acquired sphingomyelinase and lysophospholipase activity. The inositol phospholipase was found in toxic preparations from both parent and variant strains. Phospholipase A activity in culture fluids of two strains grown under various conditions is shown in Table 4. The enzyme was detected only in culture fluids which had $\beta$-haemolytic activity equal to or greater than 350 units $/ \mathrm{ml}$. 
Separation of inositol phospholipase and sphingomyelinase by curtain electrophoresis of toxic culture fluid from Staphylococcus aureus strain B.S.M. 24

The activity of inositol phospholipase and sphingomyelinase in the curtain electrophoresis fractions is shown in Fig. 5 where it can be seen that these enzymes were separated from one another, with some overlap. The fractions were not examined for lysophospholipase activity, but all subsequently examined preparations of sphingomyelinase have contained lysophospholipase activity also. The fractions containing inositol phospholipase were used for all the quantitative studies of this enzyme, since it was found only in very low concentrations in crude toxic preparations.

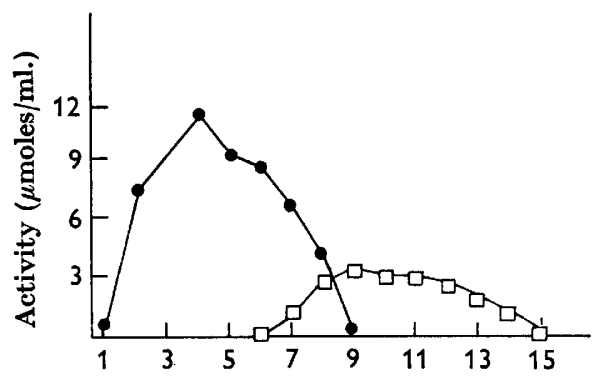

Eluate fraction number

Fig. 5

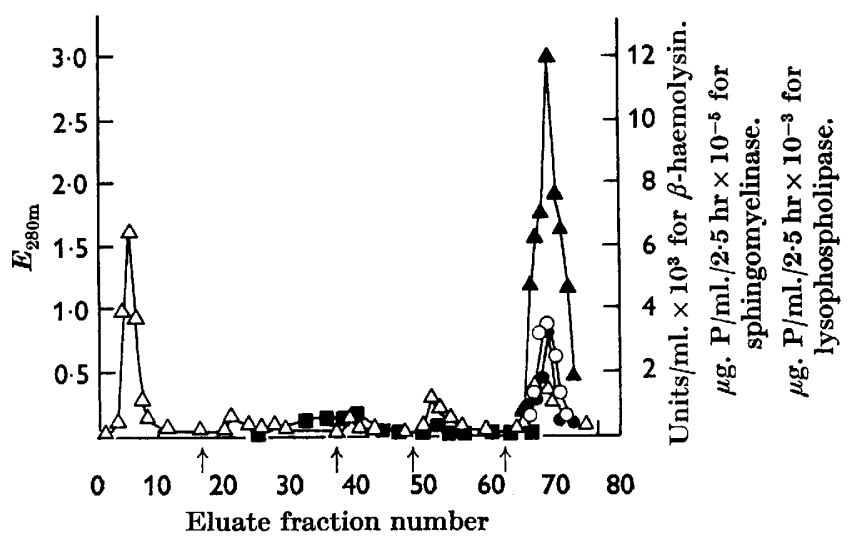

Fig. 6

Fig. 5. Activity of sphingomyelinase and inositol phospholipase in curtain electrophoresis fractions. Electrophoresis was done in veronal buffer (pH 8.6; U 0.02) at $630 \mathrm{~V}$ and $45 \mathrm{~mA}$ for $44 \mathrm{hr}$ at $4^{\circ}$. , sphingomyelinase, $\square$, inositol phospholipase.

Fig. 6. Chromatography on hydroxylapatite of $35 \mathrm{mg}$. protein of the $\left(\mathrm{NH}_{4}\right)_{2} \mathrm{SO}_{4}$ fraction from Staphylococcus aureus strain 1061-17. Eluting buffer, 0.05 M-phosphate (pH 6.7); at arrows eluents were changed successively to $0.075 \mathrm{M}, 0.10 \mathrm{M}, 0.15 \mathrm{M}$ and finally to 0.25 $\mathrm{M}$-phosphate (pH 6.7) + 0.15 M-NaCl. $\triangle$, protein; $O$, lysophospholipase; 9 , sphingomyelinase; $\square, \alpha$-haemolysin; $\Delta, \beta$-haemolysin.

\section{Purification of $\beta$-haemolysin from toxic culture fluid of Staphylococcus aureus strain 1061-17}

Fractionation of $\beta$-haemolysin with $\left(\mathrm{NH}_{4}\right)_{2} \mathrm{SO}_{4}$ resulted in a fraction containing 10,000 units $/ \mathrm{mg}$., i.e. $25 \%$ of the original activity. This fraction also contained $20 \%$ of the original sphingomyelinase activity. Figure 6 shows the results of the chromatography of $35 \mathrm{mg}$. of this fraction in phosphate buffer ( $\mathrm{pH} \mathrm{6.7)} \mathrm{on} \mathrm{hydroxylapatite.}$ This procedure was very similar to the one used by Woodin (1959) and Jackson (1963) and resulted in $\mathbf{5 0} \%$ overall recovery of the protein. This was eluted in two main peaks and some minor ones. Proteolytic activity was eluted with the starting buffer, in this case $0.05 \mathrm{M}$, and the activity approximately followed the protein concentration. After the buffer was changed to $0.075 \mathrm{M}, \alpha$-haemolysin was slowly eluted and continued to be eluted with slightly greater activity after the buffer was changed to $0 \cdot 1 \mathrm{M}$, maximum activity being found in eluate fraction 42 . When the eluting buffer was changed to $0 \cdot 15 \mathrm{M}$ a minor protein peak occurred and low concentrations of $\alpha$-haemolysin continued to be eluted. 
The second main protein peak was eluted with $0.25 \mathrm{M}$-phosphate buffer in $0.15 \mathrm{M}$ $\mathrm{NaCl}$, maximum protein concentration occurring in eluate fraction 70 . This peak contained the $\beta$-haemolysin, sphingomyelinase and lysophospholipase activities, all three of which followed symmetrical curves with maximum activity in eluate fraction 72 in each case. The $\beta$-haemolysin activity of this eluate was 37,000 units/ mg., representing a four-fold purification. Sphingomyelin was hydrolysed more readily than was lysophosphatidyl choline. When the homogeneity of eluate fraction 72 was examined on Ouchterlony plates, a single line was obtained at a protein concentration of $1 \mathrm{mg} . / \mathrm{ml}$., but after 7 days a second diffuse line appeared. Thus a correlation, which had been indicated by a variety of approaches, has been established between sphingomyelinase, lysophospholipase and a highly purified preparation of $\beta$-haemolysin.

When the eluates in the minor protein peak eluted with $0 \cdot 15 \mathrm{M}$-phosphate buffer were being studied, an additional phospholipase was identified when the eluates were incubated with plasma. Loss of phosphatidyl choline and an increase in lysophosphatidyl choline was readily detected with eluate fractions 44-66. This indicated phospholipase $\mathbf{A}$ activity and provided the first evidence that this enzyme was present in the toxic preparation. All the eluate fractions subsequent to no. 66 also hydrolysed phosphatidyl choline and, beginning with eluate fraction 68 , hydrolysis of lysophosphatidyl choline also occurred in the region of $\beta$-haemolysin activity.

It has not been possible completely to define the region of phospholipase $\mathbf{A}$ activity. Slight hydrolysis of purified phosphatidyl choline was detected by paper chromatography after incubation for $48 \mathrm{hr}$ with eluate fractions $44-60$, with weak but maximum activity with eluate fractions 53-56. Ester group analysis of this system did not give consistent results. Without further evidence dependent on quantitative analysis, it is suggested that the hydrolysis of phosphatidyl choline in plasma, by eluates which contained lysophospholipase (eluate fractions 68-78), was due to the activation of trace amounts of phospholipase $\mathbf{A}$ by the continuous removal of the end-product by the highly active lysophospholipase. The possibility that the phospholipase $\mathbf{A}$ was produced by a contaminant organism was considered. However, after exhaustive tests for bacterial purity at each stage from toxin production to the final stage of purification, this possibility was eliminated. Lipase activity was not found in any chromatographic fraction.

\section{Purification of $\alpha$-haemolysin from toxic preparations from Staphylococcus aureus strain $\mathrm{CN} 56$}

Fractionation of $\alpha$-haemolysin with $\left(\mathrm{NH}_{4}\right)_{2} \mathrm{SO}_{4}$ resulted in a fraction containing $\mathbf{4 5 , 0 0 0}$ units/mg., i.e. $25 \%$ of the original activity. The inositol phospholipase was detected qualitatively in this fraction. On chromatography of $173 \mathrm{mg}$. of this fraction in $0.1 \mathrm{M}$-phosphate buffer in the manner described for the separation of $\beta$-haemolysin, $50 \%$ of the haemolytic activity and $34 \%$ of the protein applied to the column were eluted in three well separated peaks. Two of these were eluted successively with the starting buffer and contained proteolytic and $\alpha$-haemolysin activities respectively. Lipase activity was found in the third peak, which appeared on changing the eluting buffer to $0.15 \mathrm{M}$.

Considerable purification of $\alpha$-haemolysin was achieved, the activity of eluate 
fractions near the top of the peak being 72,000 units $/ \mathrm{mg}$. When the eluate containing the highest concentration of $\alpha$-haemolysin was examined on Ouchterlony plates at a protein concentration of $0.5 \mathrm{mg} . / \mathrm{ml}$. a single reaction line was obtained; no other lines appeared after 7 days. However, a second diffuse line was seen when all the eluates on this peak were pooled, concentrated with some loss of activity and examined in a similar manner at $1 \mathrm{mg}$. protein $/ \mathrm{ml}$.

Exhaustive tests were made to trace the inositol phospholipase activity throughout the purification. The eluates of the three respective peaks were pooled, concentrated and tested for this enzyme. No concentration of the activity was detected. While the enzyme was detected in the eluates of the $\alpha$-haemolysin peak treated in this way, the activity bore no relationship to the $\alpha$-haemolysin activity. No enhancement of activity was obtained when various mixtures of these preparations were examined for the enzyme. In the absence of further purification and the failure to obtain enzyme activity when purified phosphatidyl inositol was used as substrate, no further work was done on this phospholipase.

\section{DISCUSSION}

The properties, the distribution in toxic culture fluids and the separation of the enzymes described above show that the inositol phospholipase, sphingomyelinase and lysophospholipase activities are those of two enzymes, each with a mode of action like that of phospholipase $\mathrm{C}$. Whereas the inositol phospholipase was separated from sphingomyelinase by curtain electrophoresis, no separation of sphingomyelinase from lysophospholipase has yet been achieved. The curtain electrophoresis fractions which contained the inositol phospholipase were not homogeneous and further attempts to isolate this enzyme from toxic preparations by chromatography on hydroxylapatite were not successful. No correlation was found between the activity of this enzyme and that of a highly purified preparation of $\alpha$-haemolysin or of any other component of staphylococcal toxic preparations.

The sphingomyelinase and lysophospholipase were present in crude toxic culture fluids in considerably higher concentrations than was the inositol phospholipase, and purification of the former enzymes by chromatography on hydroxylapatite was readily achieved. The distribution of these enzymes in toxic preparations from various sources and the effect of metal ions indicated a correlation between their activity and that of $\beta$-haemolysin. This was confirmed by the preparation of highly purified $\beta$-haemolysin which contained sphingomyelinase and lysophospholipase activity. Further, the sphingomyelinase and lysophospholipase activities of the chromatography eluates closely followed that of $\beta$-haemolysin rather than the concentration of protein, which itself was heterogeneous (Fig. 6). Thus until $\beta$ haemolysin and sphingomyelinase and lysophospholipase activities have been separated from one another, these may be regarded as activities of one protein. The identification of this enzymic activity with $\beta$-haemolysin is in keeping with the preferential haemolysis of sheep erythrocytes rather than rabbit erythrocytes by $\beta$-haemolysin, since the sheep cells contain a significantly higher concentration of sphingomyelin than do the rabbit cells (de Gier \& van Deenen, 1961).

The properties of the staphylococcal phospholipase $\mathrm{C}$ enzymes make interesting comparisons with the phospholipase $\mathrm{C}$ enzymes from other sources. Unlike the 
phospholipase $\mathrm{C}$ of Clostridium welchii, no preferential hydrolysis of phosphatidyl choline or phosphatidyl ethanolamine by the staphylococcal enzymes was observed. The optimal $\mathrm{pH}$ value for the staphylococcal enzymes, sphingomyelinase and lysophospholipase, was in each case near $\mathrm{pH} \mathrm{7,} \mathrm{which} \mathrm{happens} \mathrm{to} \mathrm{be} \mathrm{the} \mathrm{optimum} \mathrm{de-}$ scribed for the phospholipase C of $\mathrm{Cl}$. welchii (Macfarlane \& Knight, 1941). The inositol phospholipase which in every case hydrolysed lysophosphatidyl inositol as well as the diacyl compound, had an optimum near $\mathrm{pH} 4 \cdot 6$, close to that of the enzyme in rat liver (pH 5.4) which also hydrolysed both these phospholipids (Kemp, Hübscher \& Hawthorne, 1959).

In a former communication (Magnusson et al. 1962), a phospholipase A was reported in a staphylococcal toxic preparation from a pure $\alpha$-strain CN 56 of Staphylococcus aureus. This observation could not be repeated and it was concluded that non-enzymic hydrolysis had probably occurred. The separation of a phospholipase $\mathbf{A}$ in fractions of a toxic preparation from an $\alpha \beta$-strain, reported in the present paper, was therefore of interest. In the light of the correlation just established between $\beta$-haemolysin and lysophospholipase, a toxic preparation containing a strong $\beta$ haemolysin activity would produce conditions favourable to the activation of a phospholipase A. The continuous hydrolysis of lysophosphatidyl choline by the lysophospholipase of $\beta$-haemolysin would favour the production of a phospholipase A, providing fresh substrate for the lysophospholipase.

Finally, like other phospholipase enzymes (Condrea, de Vries \& Mager, 1962), those studied here were more active on native substrates than on purified phospholipids. It might well be that the relative activities of these enzymes in vitro might bear little relationship to those elaborated in the living animal.

Our thanks are due to Mr W. Dickson, Mr W. Gorski, Mrs I. Gunn, Mrs H. Bennett and Miss P. Russell for their valuable assistance during this work.

\section{ADDENDUM}

We thank Dr A. W. Jackson of Laboratory of Hygiene, Department of National Health and Welfare, Ottawa, Ontario, Canada, for kindly making available to us a small sample of purified $\beta$-haemolysin prepared by chromatography on hydroxylapatite. This was found on assay to contain 25 units. The phospholipase activity of this sample was examined, with plasma as substrate. It was found to contain both sphingomyelinase and lysophospholipase.

\section{REFERENCES}

Bernheimer, A. W. \& Schwartz, L. L. (1963). Isolation and composition of staphylococcal alpha toxin. J. gen. Microbiol. 30, 455.

Brown, W. D. (1954). Determination of lipid phosphorus in ultramicro quantities of serum. Aust. J. exp. Biol. med. Sci. 32, 677.

Condrea, E., de VRIEs A. \& MAGer, J. (1962). Action of snake venom phospholipase A on free and lipoprotein-bound phospholipids. Biochim. biophys. Acta, 58, 389.

De Gier, J. \& van Deenen, L. L. M. (1961). Some lipid characteristics of red cell membranes of various animal species. Biochim. biophys. Acta, 49, 286.

Doery, H. M., Magnusson, B. J., Cheyne, I. M. \& Gulasekharam, J. (1963). A phospholipase in staphylococcal toxin which hydrolyses sphingomyelin. Nature, Lond. 198, 1091. 
Doery, H. M. \& Pearson, J. E. (1961). Haemolysins in venoms of Australian snakes. Observations on the haemolysins of the venoms of some Australian snakes and the separation of phospholipase A from the venom of Pseudechis porphyriacus. Biochem. J. 78, 820.

Dolman, C. E. (1934). Ingestion of staphylococcus exotoxin by human volunteers, with special reference to staphylococcal food poisoning. J. infect. Dis. 55, 172.

Gerlach, E., Weber, E. \& Döring, H. J. (1955). Einige neue Lösungsmittel für die Papierchromatographie von Phosphorsäure-Estern. Arch. exp. Path. Pharmakol. 226, 9.

Hanes, C. S. \& Isherwood, F. A. (1949). Separation of the phosphoric esters on the filter paper chromatogram. Nature, Lond. 164, 1107.

JACKson, A. W. (1963). Purification of staphylococcal alpha-lysin. Canad. J. Biochem. Physiol. 41, 219.

JACKson, A. W. \& LitTle, R. M. (1957). Staphylococcal toxins. I. Factors affecting the haemolytic activity of alpha toxin. Canad. J. Microbiol. 3, 47.

Kemp, P., Hübscher, G. \& Hawthorne, J. N. (1959). A liver phospholipase hydrolysing phosphoinositides. Biochim. biophys. Acta, 31, 585.

Levy, E. (1952). Diffusible Products of Staphylococci. Thesis, University of London.

Macfarlane, M. G. \& KNight, B. C. J. G. (1941). The biochemistry of bacterial toxins. I. The lecithinase activity of $\mathrm{Cl}$. welchii toxins. Biochem. J. 35, 884.

Magnusson, B. J., Doery, H. M. \& Gulasekharam, J. (1962). Phospholipase activity of staphylococcal toxin. Nature, Lond. 196, 270.

Marinetti, G. V., Albrecht, M., Fond, T. \& Stotz, E. (1959). Analysis of human plasma phosphatides by paper chromatography. Biochim. biophys. Acta, 36, 4.

Pangborn, M. C. (1951). A simplified purification of lecithin. J. biol. Chem. 188, 471.

RAPPORT, M. M. \& LERNER, B. (1958). A simplified preparation of sphingomyelin. J. biol. Chem. 232, 63.

Richou, R., Richov, R., Quinchon, C. \& Pantalkon, J. (1960). On the presence, in filtrates of staphylococcal cultures, of enzymes attacking lipides (neutral fat, ovolipides, lecithin) and casein. Rev. Immunol. 24, 496.

Robinson, J., Thatcher, F. S. \& Gagnon, J. (1958). Studies with staphylococcal toxins. IV. The purification and metallic requirements of specific haemolysins. Canad. $J$. Microbiol. 4, 345.

SAUNDERS, L. (1957). Some properties of mixed sols of lecithin and lysolecithin. J. Pharm., London. 9, 834.

Shapiro, B. (1953). Purification and properties of a lysolecithinase from pancreas. Biochem. J. 53, 663.

Tiselius, A., Huerten, S. \& Levin, Ö. (1956). Protein chromatography on calcium phosphate columns. Arch. Biochem. Biophys. 65, 132.

van Beers, G. J., DE Iongh, H. \& Boldingh, J. (1958). Isolation of phospholipids by dialysis through a rubber membrane. Essential Fatty Acids, p. 43. Ed. by H.M. Sinclair, London: Butterworths Scientific Publications.

Woodin, A. M. (1959). Fractionation of a leucocidin from Staphylococcus aureus. Biochem. J. 73, 225. 